\title{
Analysis of consumption and ensuring energy resources of the Dnipropetrovsk Region
}

\author{
Myroslav Syvyi ${ }^{1}$, Natalia Panteleeva ${ }^{2,}$, Liudmyla Burman ${ }^{2}$, Olga Kalinichenko ${ }^{2}$, and Mykhailo Provozhenko ${ }^{2}$ \\ ${ }^{1}$ Ternopil Volodymyr Hnatiuk National Pedagogical University, 2 Maxyma Kryvonosa Str., Ternopil, 46027, Ukraine \\ ${ }^{2}$ Kryvyi Rih State Pedagogical University, 54 Gagarina Ave., Kryvyi Rih, 50086, Ukraine
}

\begin{abstract}
The issue of energy-saving and energy efficiency is actual at the present-day development of Ukraine's economy. The imperfective system of energy ensuring as the result of inefficient energy resources utilization is a characteristic feature of the state. The analysis of ensuring energy resources applied to Dnipropetrovsk Region as one of the leading industrial regions of the country is presented in the article. The availability of reserves and production of fuel resources was analyzed in it. Distinctive features of energy resources consumption with the aim of assessment general and partial indexes of energy ensuring and fuel power-intensity of the region's economic complex are highlighted in the work. The tendencies and perspectives of energy consumption development of the Dnipropetrovsk Region were analyzed herewith.
\end{abstract}

\section{Introduction}

The problems of ensuring any country with its own fuelenergy resources are considered as the most acute and urgent ones because they refer to a country's energy safety. Under conditions of formation and realization of energy ensuring strategy and optimizing energy consumption resources, which are the basis of a territory economy development, the issue of sufficient volume of fuel energy resources availability for renewable processes in industries of the national economy as well as ensuring energy, economical and correspondently national security arises acutely [1].

Fuel-energy resources as any other resources are located very much unevenly on the territory of the country. So there arises the necessity of exploring deposits, their extraction, beneficiation, processing and transportation which stipulates the development of mining industry. Energy safety, in its turn, demands the assessment of resource and energy potential of the territory, includes the control over energy resources, energy-saving and energy efficiency.

Crisis periods in economy, fuel price fluctuations and the present-day environmental challenges demand a transition from increasing output of traditional to renewable energy resources. Monitoring the resource base of fuel energy raw materials remains actual, in particular, the regional analysis of characteristic features of consumption and ensuring fuel energy raw materials by individual regions of the country.

The issues of the country's (a region's, a territory's) energy safety were comprehensively researched in the works of A. Yerina [22], O. Kolodiazhna [22], V. Lir [17], V. Mykhailov [11], M. Mazur [3] et al. Ensuring mineral energy resources and rational nature management were considered in the works of M. Korzhniev [23], Ye. Yakovliev [23], M. Syvyi [20] and others. They concerned the analysis of the presentday status of Ukraine's mineral-and-raw material base, solving the problems of development and restructuring mineral raw deposits, improvement of the system of state management for mineral resources use. Much attention is paid to the problems connected with the usage of nontraditional sources of hydrocarbons. S. Vakarchuk [9], M. Syvyi [21], N. Khomenko [10] carried out the study of methane use and extraction possibilities at coal deposits, shale gas - by S. Vakarchuk, O. Zeikan and others [9]. Hence, the problem of formation of stable energy ensuring remains actual and demands further researching.

The purpose of the research is the analysis of energy resources consumption by the Dnepropetrovsk Region and providing its needs for fuel-and-energy raw materials; assessment of the role and place in the structure of consumption energy resources of own extraction, as well as the present status of energy extracting industry; revealing the problems and perspectives of its development.

\section{Energy resources consumption in the Dnepropetrovsk Region}

The Dnipropetrovsk Region is one of the major industrially developed territories of Ukraine, the development of which is grounded on mineral resources extraction and processing, steel making, mechanical engineering, chemical industry that have high indexes of power-consumption. The Region's share in the national industrial production made up $22.5 \%$ in 2018 and the Region ranks the first place in Ukraine by this index.

Corresponding author: panteleeva4y@gmail.com 
The Region is also one of the biggest energy resources consumers (Fig. 1) [2].

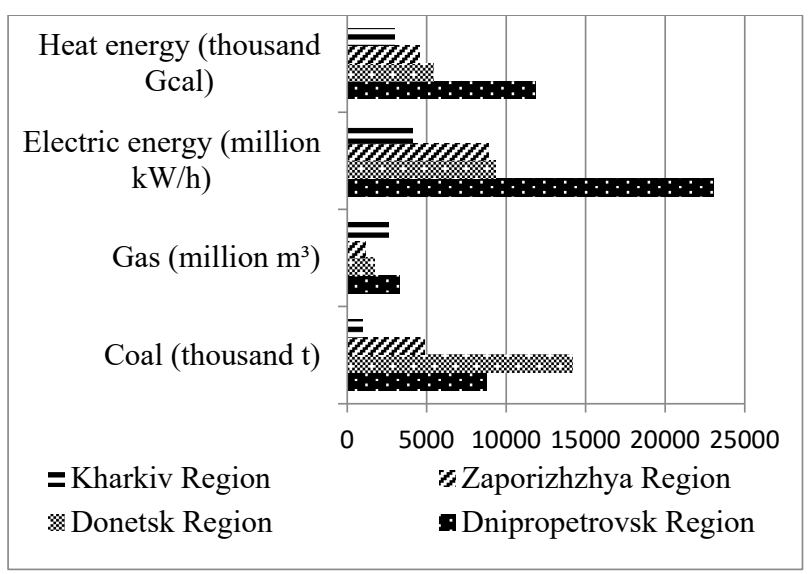

Fig. 1. The place of the Dnipropetrovsk Region among Ukraine's regions in relation to various energy sources consumption in 2018 (on the basis of Dniprostat data).

In the opinion of M. Mazur it is typical for the territory to use fuel energy resources (FER) in stages: ensuring formation of the resource base; fuel energy resources extraction; energy generating and transformation; fuel and energy transportation; energy and fuel consumption. Each stage is characterized by indexes of powerconsumption, usefulness of the resources, fuel energy resources losses.

Reducing in losses at each stage will allow to involve energy-saving potential, and the use of unconventional sources of energy will allow replacement potential of nonrenewable resources by renewable ones and minimize the negative environmental impact [3].

By the year 2018 in the structure of Ukraine's energy resources consumption the volumes of coal prevailed $(39.2 \%)$ that of coke and semi-coke from coal; gas coke $(28.6 \%)$ and natural gas (13.8\%) [4]. Fig. 2 illustrates energy resources consumption from 2011 up to 2018 period. The tendency of decreasing natural gas consumption and increasing coal and coke usage was observed through this period.

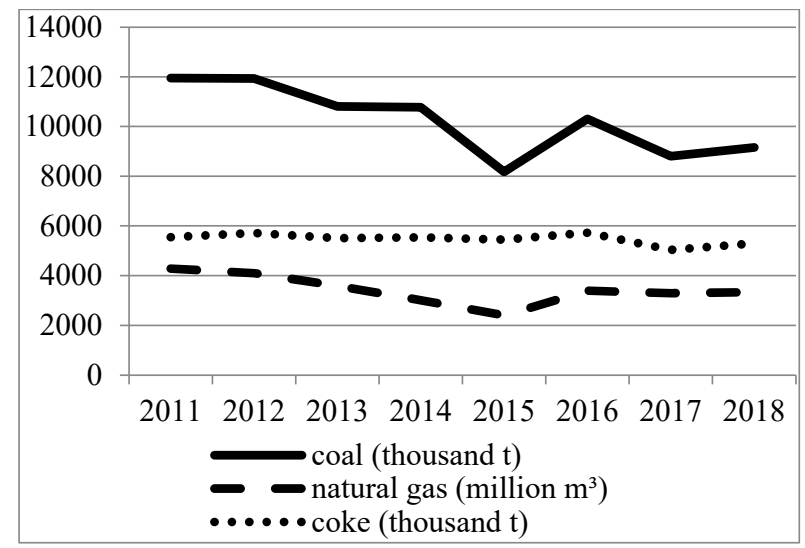

Fig. 2. The dynamics of energy resources consumption in the Dnipropetrovsk Region during the period of 2011-2018 [4].

The generalized index characterizing a region's economic growth at the regional level is Gross Regional
Product (GRP), which can be applied to calculation a production's fuel energy capacity. Economical indexes of the Region during the years 2014-2015 had the tendency of decreasing due to the economic crisis. General drop in the Region's economy at that period amounted almost to $12.5 \%$. Since 2016 economic situation in the Region has stabilized and the rates of growth have been gradually recovered (Table 1). The coefficient of fuel energy capacity index calculated by the authors is a ratio of GRP to the fuel consumed. It illustrates general efficiency of fuel consumption in the Dnipropetrovsk Region on the basis of GRP ratio per one hryvna (UAH). As seen from Table 1, fuel consumption in the Region has a stable tendency to decrease, though the level of fuel energy capacity remains rather high. It is important for the Region's steady development that economic growth would be synchronized with decreasing of GRP fuel energy capacity.

Table 1. The dynamics of general level of fuel energy capacity the Dnipropetrovsk Region during 2010-2017 [GRP] [5].

\begin{tabular}{|c|c|c|c|}
\hline Years & $\begin{array}{c}\text { Fuel consumed } \\
\text { (thousand ton of } \\
\text { conditional fuel) }\end{array}$ & $\begin{array}{c}\text { GRP in } \\
\text { actual prices } \\
\text { (million } \\
\text { UAH) }\end{array}$ & $\begin{array}{c}\text { Fuel energy } \\
\text { capacity coefficient } \\
\text { (kg, conditional } \\
\text { fuel / UAH) }\end{array}$ \\
\hline 2010 & 23074,6 & 116136 & 0,198 \\
\hline 2011 & 22838,9 & 140020 & 0,163 \\
\hline 2012 & 21980,3 & 147970 & 0,148 \\
\hline 2013 & 21199,1 & 152905 & 0,138 \\
\hline 2014 & 18159,8 & 176540 & 0,109 \\
\hline 2015 & 21200,0 & 215206 & 0,098 \\
\hline 2016 & 19203,0 & 244478 & 0,078 \\
\hline 2017 & 19900,0 & 313830 & 0,063 \\
\hline
\end{tabular}

In the structure of the fuel consumed according to the types of economic activities by the main consumers there are enterprises of steel production, their share made up $63.1 \%$ of total volume of consumption. So, the measures for energy-saving in steel production are of top priority.

There are over 500 industrial enterprises on the territory of the Region. From the territorial point of view, the main fuel consumers are three cities: Kryvyi Rih (46\%), Dnipro (19\%) and Kam'yanske (18.3\%). Unit weight of coke consumption by Kryvyi Rih enterprises makes up $65 \%$ of total consumption, natural gas $-47.4 \%$, coke $-30.4 \%$ [6].

Thermal power stations are significant sectoral consumers of energy resources in the Region: Kryvyi Rih TPS (2892 MW output) and Prydniprovsk TPS (1765 MW output) which are included into the united power system of Ukraine and they are coal-based operating [6].

The Dnipropetrovsk Region is one of the most urbanized regions in Ukraine. 20 cities, 46 towns and 1435 villages are located on the Region's territory. The share of city population in the Region makes $83.61 \%$ as per average index of $69.23 \%$ in Ukraine. That is why the major Region's gas consumers are the population, industry and government-financed organizations (Fig. 3). The statistics data analysis of natural gas consumption by the population in 2018 showed that volumes of 
realization dropped by $20 \%$ as compared to the previous year due to gas price changes, and the use of firewood for heating raised almost by 6 times.

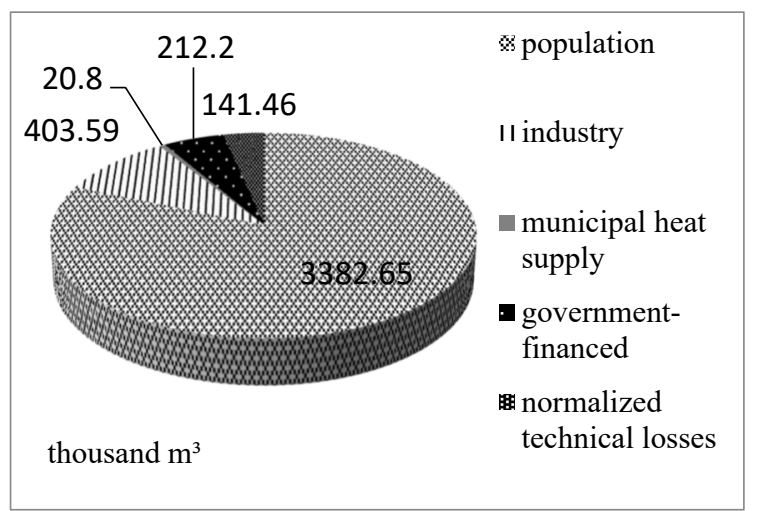

Fig. 3. Natural gas consumption by consumer categories in the Dnipropetrovsk Region, thousand $\mathrm{m}^{3}$ (2018) [6]

To make assessment of the Dnipropetrovsk Region ensuring with its own fuel energy resources (hydrocarbons, hard and brown coals) it is necessary to analyze the present day status of their deposits, demand, the ways of technical re-equipment and restricting the mining industry.

\section{Fuel mineral resources extraction in the Dnipropetrovsk Region}

The deposits of fuel energy raw materials in the Dnipropetrovsk Region are exploited for a long time (gas, oil, hard coal) hence, some of them (brown coal) remain unclaimed or need further researching (unconventional types).

\subsection{Natural gas and oil}

15 hydrocarbon deposits have been registered [7] in the Dnipropetrovsk Region, the major part of which are integrated ones, namely 4 gas fields, 5 gas-condensate fields, 7 oil-and-gas-condensate fields, out of which 12 are exploited and 3 are being explored.

Oil and gas fields are located in the north-east of the Dnipropetrovsk Region and belong to the DniproDonetsk oil- and gas-bearing region (DDOGR). Referring to tectonic aspect DDOGR is located within the Dnipro-Donetsk depression (DDD). The depression was formed with thick rock sediments aging from Middle Devon to Neozoic.

Hydrocarbon deposits on the territory of the Dnipropetrovsk Region belong to RudenkivskoProletarskyi oil-gas-bearing region the main part of which is located within the Poltava Region. The region is attached to the south-east side-board of the DDD and presented by hydrocarbon deposits in sediments of the Middle, Lower Carbon and Devon. In the boundaries of the Dnipropetrovsk Region there is MykhailivskoLeventsivska zone of oil-gas accumulation.

Many of the explored deposits belong to the small categories having less than 5 billion $\mathrm{m}^{3}$ of gas reserves.
Separate deposits of medium size (Proletarske, Ul'yanivske) are substantially exhausted and do not make any difference from others (Table 2). The deposits' free gas is high-caloric (30-40 thousand $\mathrm{kJ})$, being mainly sulfur-free, with minor nitrogen and carbonoxide gas content. Gas consistency in relation to the air varies from 0.556 to 1.1 . The current state of fixed condensate in gas is changing from 1 to $2265 \mathrm{~g} / \mathrm{m}^{3}$. An average ethane, propane, butanes content in free gas makes correspondently: 5,58; 2,06; $0,74 \%$; helium $0.07 \%$ [7].

Gas reserves make about $1.5 \%$, oil reserves $0.9 \%$ and gas condensate $2 \%$ of the national ones (Table 2 ).

Table 2. Distribution of reserves (by 01.01.2019) and hydrocarbon extraction (2017) among the deposits in the Dnipropetrovsk Region (on the basis of Geoinform data).

\begin{tabular}{|c|c|c|c|c|c|c|}
\hline \multirow[b]{2}{*}{ Deposit } & \multicolumn{2}{|c|}{$\begin{array}{l}\text { Oil (thou- } \\
\text { sand t) }\end{array}$} & \multicolumn{2}{|c|}{$\begin{array}{c}\text { Gas (million } \\
\mathbf{m}^{3} \text { ) }\end{array}$} & \multicolumn{2}{|c|}{$\begin{array}{c}\text { Gas con- } \\
\text { densate } \\
\text { (thousand } t)\end{array}$} \\
\hline & \begin{tabular}{|c|} 
Ex- \\
trac- \\
ting \\
balan- \\
ce re- \\
serves \\
\end{tabular} & \begin{tabular}{|c} 
Out- \\
put
\end{tabular} & $\begin{array}{l}\text { Extrac- } \\
\text { ting } \\
\text { balance } \\
\text { reser- } \\
\text { ves }\end{array}$ & $\begin{array}{l}\text { Out- } \\
\text { put }\end{array}$ & $\begin{array}{c}\text { Ex- } \\
\text { trac- } \\
\text { ting } \\
\text { balan- } \\
\text { ce re- } \\
\text { serves }\end{array}$ & $\begin{array}{l}\text { Out- } \\
\text { put }\end{array}$ \\
\hline $\begin{array}{l}\text { Mykhailivske } \\
\text { (OGCD) }\end{array}$ & - & - & 332 & 6 & - & - \\
\hline $\begin{array}{l}\text { Pereschepynske } \\
(\mathrm{GCD})\end{array}$ & 8 & - & 2131 & 44 & 119 & 1 \\
\hline Bagatoiske (GCD) & - & - & 1726 & 69 & 165 & 2 \\
\hline Golubivske(OGCD) & 526 & 3 & 412 & - & 24 & - \\
\hline Leventsivske (GCD) & - & - & 307 & 25 & - & - \\
\hline Yuriiyvske (OGCD) & 18 & 1 & 164 & 2 & 5 & - \\
\hline $\begin{array}{l}\text { Lychkivske } \\
(\mathrm{OGCD})\end{array}$ & 73 & 2 & 64 & 6 & 4 & 1 \\
\hline $\begin{array}{l}\text { Kremenivske } \\
\text { (OGCD) }\end{array}$ & 367 & 5 & 1828 & 39 & 83 & - \\
\hline $\begin{array}{l}\text { East-Novoselivske } \\
\text { (GCD) }\end{array}$ & 28 & - & 1313 & 48 & 200 & 1 \\
\hline $\begin{array}{l}\text { Novoselivske } \\
\text { (GCD) }\end{array}$ & 1 & - & 315 & 2 & - & - \\
\hline $\begin{array}{l}\text { Vynogradivske } \\
\text { (GCD) }\end{array}$ & - & - & 300 & 6 & 1 & - \\
\hline Proletarske (GCD) & 1355 & - & 1521 & 105 & 43 & 1 \\
\hline Ul’yanivske & 23 & - & 1955 & 199 & 48 & 2 \\
\hline Musiyenkivske & - & - & 332 & - & - & - \\
\hline Total & 2399 & 11 & 12700 & 551 & 692 & 8 \\
\hline
\end{tabular}

Three projects (two deposits and one area) Ryaskivske, Musiyenkivske, East-Golubivsk are prospective for oil and gas extraction after carrying out a complete volume of geologic exploration works. But a detailed geologic exploration of the underground resources and provision of the necessary facilities for the deposits demand considerable investments [7].

The following companies such as Joint Stock Company "Ukrgasvydobuvannya" and PJSC "Ukrnafta" are dealing with oil, gas and gas condensate extraction on the territory of the Region.

As seen from the Fig. 4, there exists a considerable unbalance in the Region between the levels of consumption and supplying its own energy resources. Energy safety demands searching for efficient decisions 
related to regulation of available resources consumption.

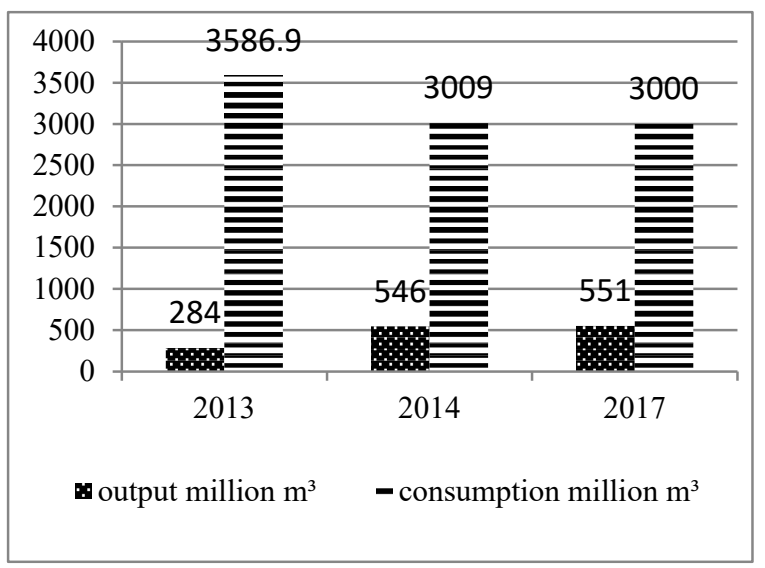

Fig.4. The dynamics of gas extraction and consumption in the Dnipropetrovsk Region in 2013-2017 [4].

The tendency in drop of the level of natural gas consumption and its import in Ukraine has been observed since 2016, which is undoubtedly a positive factor. At the same time, by the current decreased level of consumption - over 30 billion $\mathrm{m}^{3} / \mathrm{year}$ - the country is not able to provide itself with its own resources (20 billion $\mathrm{m}^{3}$ /year). The Government's Decree "On Approval the Concept of Gas Extracting Industry Development in Ukraine" dated on December 28, 2016 No.1079 set the target: to produce 27 billion $\mathrm{m}^{3}$ in 2020 , though it is not realistic due to the lack of financial means for substantial expanding geologic exploration works, introducing up-to-date methods of intensifying exploration, maintenance and development of gas industry.

At present, there are only solitary instances of applying up-to-date methods of intensifying exploration. Beginning from September 2016 JSC "Ukrgasvydobuvannya" got additional 261 million cubic meters of gas in the Ul'yanivske field at the cost of carrying out works for beds (layers) intensification by the method of hydraulic breaking (HB). Hydraulic breaking (HB) works were performed by the Belorussian state-owned company "Belorusneft".

\subsection{Brown coal}

Brown coal fields are concentrated in Verhnyodniprovsk, Synel'nykove and Petrykivka districts of the Dnipropetrovsk Region and attached to the Dniprovsk brown coal field of the West Donbas. The brown coal deposits belong to the Paleozoic (Lower, Middle Carbon) and Neozoic ages (palaeogene).

The Paleozoic deposits are spread out in Petrykivka geologic-industrial district of the West Donbas and attached mainly to Samara coal-bearing, partially to Mezhive formation of Lower and Mospine formation of Middle Carbon. Highly metamorphized brown coal of Petrykivka deposit with total reserves of 0.3 billion ton belongs mainly to so-called saline coals and has the increased content of water-soluble natrium salts, for this reason its exploration has been stopped.
Coal-bearing Palaeogene (Neozoic) age deposits are attached to multiple depressions on the surface of Ukrainian shield. Paramount volume of balance reserves of coal industrial categories is concentrated in the Dnipropetrovsk Region - not less than 1 billion ton, or $55.6 \%$ of the total reserves in the Basin. The Dnipro Basin deposits are suitable for open exploitation of such categories as $\mathrm{A}+\mathrm{B}+\mathrm{C}_{1}-519.6$ million $\mathrm{t}, \mathrm{C}_{2}-$ 8.9 million $\mathrm{t}$; extra-balance -32.0 million $\mathrm{t}$. The balance reserves of $\mathrm{A}+\mathrm{B}+\mathrm{C}_{1}$ categories, suitable for the deposits open mining, are concentrated mainly in the Kirovograd (254.5 million $\mathrm{t}-49 \%$ ) and the Dnipropetrovsk Regions (246.4 million $\mathrm{t}-47 \%$ ).

On the territory of the Dnipropetrovsk Region and partially in the neighboring regions there are three geologic-industrial districts: Verkhnyodniprovsk (partially in the Kirovograd and Zaporizhzhya Regions) - 19 deposits; Orihiv in the Zaporizhzhya and Dnipropetrovsk Regions - 2 deposits (Orihivske and Sanzharivske) and 4 areas, Kryvyi Rih in the Dnipropetrovsk, partially in the Mykolaiyiv and the Kherson Regions - 4 deposits (Apostolovske, VeseloTernivske, Guriyske, Pichuginske).

Geologic structure of the deposits is presented with spongy, sandy-and-clay rocks of Paleogene, Neogene and Quaternary ages of cover thickness up to $100 \mathrm{~m}$ varying mainly from 50 to $70 \mathrm{~m}$, which fill depressions in crystalline foundations. The main coal-bearing concentration is attached to the Buchatska formation of the Eocene section of the Paleogene system. This factor determines the deposits and sections morphology, which have lens-like shape deposits of the complicated irregular configurations. Deposits extensions vary from several meters up to several kilometers.

General number of beds makes up from 1 to 3, average covering thickness accounts for 3-6 meter, up to 20 meter at maximum. Occurrence depth of coal beds varies from 10 to 150 meter. Coal is soft brown, humite and humite-lipto-biolithe.

Brown coal reserves of the Dniprovsk Basin and its distribution among deposits and administrative districts of the Region are shown in Table 3.

Occurrence of coal beds in the thickness of spongy sandy-and-clay rocks causes a strong water-cut of plots. The coefficient of rock moisture capacity of the normally operating enterprises usually makes up about $10 \mathrm{~m}^{3}$ of water per 1 ton of coal extracted. Water-bearing horizons, which complicate the mining works, are distinguished into under-coal one which is located in the rocks of under-coal and over-coal bed which occurs higher of coal beds.

Brown coal is suitable for caking, semi-coking, gasifying, production of artificial earth wax.

The reserved plots for brown coal open-pit mining are at Verkhnyodniprovske and Synel'nykove deposits in the Dnipropetrovsk Region (Table 3).

At Verkhnyodniprovske deposit the reserves for open mining account for 146.44 million t. Mining and geologic conditions are favorable: coal bed thickness is $10.6 \mathrm{~m}$; industrial coefficient of uncovering makes $6.6 \mathrm{~m}^{3} / \mathrm{t}$; humidity $51 \%$; ash content $18.7 \%$; bitumen content $8.3 \%$; coal combustion heat $2290 \mathrm{kcal} / \mathrm{kg}$. It is 
possible to arrange a quarry here with annual output of 4.0-4.7 million t. Apart from favorable geologic conditions the deposit is located in ecological zone of the Dnipro river. Its allocation for mining may have environmental impact upon the river.

Table 3. Brown coal deposits of the Dnipropetrovsk Region.

\begin{tabular}{|c|c|c|c|c|}
\hline \multirow[b]{2}{*}{ Object location } & \multicolumn{3}{|c|}{$\begin{array}{c}\text { Reserves by the end of } \\
2017, \text { thousand } t\end{array}$} & \multirow{2}{*}{$\begin{array}{l}\text { Extra- } \\
\text { balance } \\
\text { reserves }\end{array}$} \\
\hline & $\mathbf{A}+\mathbf{B}+\mathbf{C}_{1}$ & $\mathbf{C}_{2}$ & $\begin{array}{l}\text { Confirmed } \\
\text { reserves } \\
\mathrm{A}+\mathrm{B}+\mathrm{C}_{1}\end{array}$ & \\
\hline \multicolumn{5}{|c|}{ Reserved plots of "a" group for open-pit mines } \\
\hline $\begin{array}{l}\text { Petrivska } \\
\text { Synel'nykove District }\end{array}$ & 73284 & & 73284 & \\
\hline $\begin{array}{l}\text { Verkhnyodniprovska } \\
\text { Verkhnyodniprovsk } \\
\text { District }\end{array}$ & 146443 & & 146443 & 1673 \\
\hline \multicolumn{5}{|c|}{ Perspective plots for mines exploration } \\
\hline \multicolumn{5}{|c|}{ Verkhnyodniprovsk District } \\
\hline Sokolivska & 0 & 72621 & & \\
\hline Shyrokivska & 47944 & & 48255 & 7550 \\
\hline Pivnichno-Skhidna & 0 & 95055 & & 5866 \\
\hline №3 Deposit & 4238 & & 4238 & 2213 \\
\hline $\begin{array}{l}\text { Novooleksandrivska } \\
\text { the mine's field }\end{array}$ & 72635 & 65599 & 72635 & \\
\hline Karnauhivska & 203360 & 6940 & 44604 & 27004 \\
\hline $\begin{array}{l}\text { №1-5 plots of the } \\
\text { mine's fields }\end{array}$ & 41652 & & 41652 & 5632 \\
\hline №6 Deposit & 24082 & & 24082 & 2284 \\
\hline №1 Deposit & 6490 & & 6490 & 1589 \\
\hline Pivdenna & 74600 & 7133 & 73864 & 14962 \\
\hline Pivnichna & 50567 & & 48555 & 5272 \\
\hline \multicolumn{5}{|c|}{ Petrykivka District } \\
\hline Plots №1,2 & 84359 & & 135905 & 61288 \\
\hline Plots№3-4 & 56384 & & 109543 & 91036 \\
\hline Plots№5,6, & 145956 & & & 183508 \\
\hline \multicolumn{5}{|c|}{ Synel'nykove District } \\
\hline Pivdenna & 69333 & 10705 & 69333 & 8915 \\
\hline Pivnichna & 192598 & & 157356 & 36559 \\
\hline \multicolumn{5}{|c|}{ Perspective plots for open-pit mine exploration } \\
\hline $\begin{array}{l}\text { Verkhnyodniprovska } \\
\text { outside the technical } \\
\text { bounds of open-pit } \\
\text { mine }\end{array}$ & 11927 & & 11927 & 235 \\
\hline $\begin{array}{l}\text { Petrivska } \\
\text { Remained reserves of } \\
\text { Synel'nykove Deposit }\end{array}$ & 14008 & & 14008 & 2058 \\
\hline \multicolumn{5}{|c|}{ Vacant plots near operating open-pit mines } \\
\hline $\begin{array}{l}\text { Verkhnyodniprovska } \\
\text { outside the technical } \\
\text { bounds of open-pit } \\
\text { mine }\end{array}$ & 784 & & 784 & 69 \\
\hline
\end{tabular}

Petrivska plot with reserves of 73.28 million $t$ and $9.1 \mathrm{~m}^{3} / \mathrm{t}$ coefficient of uncovering has been explored at Synel'nykove brown coal deposit with total reserves of 350 million $\mathrm{t}$ for open mining. Coal humidity is $58 \%$; sulfur content $-4.8 \%$; ash content $-20.8 \%$; bitumen content $-7.4 \%$; coal combustion heat amounts to $1810 \mathrm{kcal} / \mathrm{kg}$. Mining and geologic conditions are difficult.

Other deposits in the Dnipropetrovsk Region were explored earlier and can be mined exclusively by the underground method.

Taking into account the tendency of curtailing the usage of nonrenewable natural resources the beginning of brown coal mining in the region is economically unreasonable.

\subsection{Hard coal}

Ukraine takes first place in Europe relating to hard coal reserves, its resources account for 117,2 billion t, and the explored coal makes up 45.8 billion $t$. Out of the explored reserves 25 billion $t$ belong to the West Donbas. Within the territory of the Dnipropetrovsk Region there are deposits of Pavlogradsk-Petropavlivsk, Novomoskovsk and Petrykivsk geologic-industrial districts. Coal mining is carried out only in PavlogradskPetropavlivka geologic-industrial district where 10 mines of JSC "DTEK Pavlogradvugillya" operate (Table 4).

Table 4. Coal output at JSC "DTEK Pavlogradvugillya" mines in 2018 [8].

\begin{tabular}{|l|c|c|c|}
\hline \multicolumn{1}{|c|}{ Mine's name } & $\begin{array}{c}\text { Reserves by } \\
\mathbf{0 1 . 0 1 . 2 0 1 7}\end{array}$ & Output, $\mathbf{t}$ & $\begin{array}{c}+/- \text { as to the } \\
\text { preceding year }\end{array}$ \\
\hline Stepova & 1932289 & 231212 & 20194 \\
\hline Pavlogradska & 45467 & 61005 & -143495 \\
\hline Yuvileiyna & 73306 & 133848 & 46924 \\
\hline Blagodatna & 81420 & 139900 & -30873 \\
\hline Ternivska & 60892 & 119490 & 990 \\
\hline Samarska & 77756 & 154429 & 13005 \\
\hline Dniprovska & 127504 & 102362 & -23080 \\
\hline Geroiyv Kosmosu & 192406 & 265118 & -452 \\
\hline West-Donbaska & 233079 & 131100 & -36556 \\
\hline Stashkov mine & 51973 & 191079 & 91631 \\
\hline
\end{tabular}

The area of the part of deposits being mined accounts for about 600 square kilometers. Industrial coal-bearing is attached to sediments of Samara formation $\mathrm{C}_{1}{ }^{3}(\mathrm{C})$ of the lower part of Serpukhov layer of lower Carbon. Samara formation is characterized by a considerable development mainly of low-yield coal beds and interfacial layers. Coal beds are alternated with argillite, aleuroliths, sandstones and lime-stones.

Coal beds of $\mathrm{C}_{1}{ }^{3}(\mathrm{C})$ formation of PavlogradskPetropavlivsk geologic-industrial district corresponds to long-flaring; long-flaring and gassy; gassy brands. Coal of long-flaring brand is partially spread in the western part of Pavlogradsk-Petropavlivsk geologic-industrial district, long-flaring an, gassy - mainly in the central part and gassy brand - in the eastern part. Coal of "Geroiyv Kosmosu", "Blagodatna", "Pavlogradska", "Ternivska", "Dniprovska" mines belongs to longflaring, gassy brand, the rest - to gassy brand. Coal of long-flaring brand can be used as energy and municipal fuel with a prospect of using it in chemical and partially in coke-chemical industries. Coal beds of Samara formation of gassy brand in Pavlogradsk-Petropavlivsk district, as of that in West Donbas in general, do not differ for their petrography content from coal of longflaring, gassy brand. In the long term the coal reserves of long-flaring, gassy brand are a basis for production of squeezed coke and obtaining synthetic fuels. At present 
the main purpose of coal use is power engineering. The main purpose of gassy brand coal usage in the eastern part of Pavlogradsk-Petropavlivsk geologic-industrial district is in coke-chemical industry.

A considerable part of the area under extraction comes to the river overflows, industrial and civil objects. Under the overflows of the Samara, Ternivka, Mala Ternivka rivers 186.3 million $\mathrm{t}$ of coal are bedded and under civil and industrial structures -412 million $t$ [7]. Such settlements as Blagodatne, Verbky, Ternivka, Rosyshky, Samarske and others get location in mining zone. Moreover, in the area of coal mine fields there runs Kyiv - Donetsk motor road and the railway sections.

The potential capabilities for increasing energy and coke coals are available in the Dnipropetrovsk Region.

Large reserves of energy coal are concentrated in Novomoskovsk District, but this coal belongs to a saline one. It has an increased content of water-soluble salts of sodium inherited from the marine conditions of coal accumulation [7].

Taking into account the world tendencies towards curtailing the use of energy coal, its production must be carried out within the volumes of existing needs. Hence, due to available technologies, steel production retains the need of steadily supplying the industry with coke coal. Therefore, there is an acute problem of technological reequipment in coal mining industry, which will allow optimizing coal output volumes in the region.

\section{Alternative sources of hydrocarbon raw materials}

\subsection{Methane gas of coal deposits}

In the context of energy source diversifying the problem of utilizing alternative types of hydrocarbon raw materials arises acutely. Coal-bearing deposits of Donbas (coal beds as well as coal-bearing rocks), which contain methane considerable resources, can serve for its industrial production and should be taken up as gas-coal deposits. Methane of coal deposits is a widespread energy raw material and its reserves are rather huge, and the real volume suitable for extraction exceeds 3.0-3.5 trillion $\mathrm{m}^{3}$, which overruns substantially gas reserves of the rest fields of Ukraine. It is necessary to carry out gascoal deposits mining in an integrated way for separate extraction coal and methane. In so doing, the methane resources are estimated as an accompanying useful mineral. It is technologically necessary to remove it for providing safe works during coal mining operation, or as an individual useful mineral which is extracted irrespective of coal beds mining on the principles of economic feasibility and profitability.

By the assessment of national and foreign experts, Ukraine takes the fourth place in the world after China, Russia and Canada for its methane reserves potential at coal deposits.

Total resources of the mine methane in rocks and coal beds vary by different assessments from 4-6 up to 22.2 trillion $\mathrm{m}^{3}$. The industrial share makes 11.9 trillion $\mathrm{m}^{3}$ out of 3.3 trillion $\mathrm{m}^{3}$ forecasted are suitable for extraction [9]. A considerable part of total methane reserves in coal-bearing rocks makes up occluded and fixed methane for extracting of which introducing efficient technologies for mining worksand technical tools by using foreign countries' experience are required.

Methane as an accompanying useful mineral is contained in coal beds of Carbon age in the east of the Region within Pavlogradsk-Petropavlivsk geologicindustrial district. Natural methane-bearing capacity of coal-bearing deposits changes, at average, from 5 up to $30 \mathrm{~m}^{3} / \mathrm{t}$ of dry ash-less mass [7]. Coal beds are characterized by primary and post-sedimentation folding and are natural traps, where methane is in a free condition. The depths from $350 \mathrm{~m}$ to $1000 \mathrm{~m}$ are considered optimal for methane extraction out of coal beds of low-medium and medium grade of metamorphism. The mines of Pavlogradsk-Petropavlivsk district of West Donbas correspond to such geotectonic conditions. Regional strata dislocation is not high, thickness up to $3 \mathrm{~km}$ with minor cata-genetic transformations, increased porosity and perviousness. Coal beds covering consists of rocks containing aleurolite-and-argillite with minor layers of sandstones, which enables methane conservation. Collectors of methane serve fractured reservoirs [10]. Coal mine fields of Pavlogradsk-Petropavlivsk district are located within the Central graben (sunken block) and are limited by Shevchenkivskyi and Bogdanivskyi faults. Coal beds plunge in monoclonal way at an angle $3-5^{\circ}$ to the north, north-east with rocks strike in the western and northwestern directions. During research it was determined that positive gas anomalies within Geroiyv Kosmosu mine of Pavlogradsk-Petropavlivsk district are located within synclinal flexure, which stretches alongside Bogdanivskyi fault. Positive anomalies of free methane content deviation on the mine's field are connected with synclinal folds, one of which was formed near Bogdanivskyi fault and another - in a syncline wing near Blagodatnenskyi fault. Separate anomalies are situated within great anticline structure. Data statistics processing of nine mines' fields in Pavlogradsk-Petropavlivsk district performed by N. Khomenko showed that in folds and wings of syncline structures over $50 \%$ of additive gas-bearing anomalies and $67 \%$ anomalies with free methane content concentrate [10].

Research works for studying possibilities of industrial extraction methane from Donbas coal thickness with selection of plots for setting up pilot projects were carried out [11] among the others in Petrykivka-Novomoskovsk area (southern bench of marginal through part of the Dnipro-Donetsk depression) and in Pavlogradsk-Petropavlivsk (in the southern zone of Donbas minor folding).

In Pavlogradsk-Petropavlivsk district the resources of $\mathrm{HC}$ (hydro-carbonaceous) gases in coal beds and layers in the operating mines (mine fields) account for: in coal 11.7 billion $\mathrm{m}^{3}$, in satellites $\mathrm{CK}=0.5$ (total) 6.1 billion $\mathrm{m}^{3}$ with reservoir thickness of $0.3 \mathrm{~m}-2.3$ billion $\mathrm{m}^{3}$, (on the exploration plots) in coal 4.4 billion $\mathrm{m}^{3}$, in satellites (total) 5.8 billion $\mathrm{m}^{3}$, with reservoir thickness of $0.3-$ $2.3 \mathrm{~m}$.

Comparing to other geologic-industrial districts of Donbas, where hydro-carbonaceous gas resources were 
calculated, Pavlograd-Petropavlivsk district is characterized by mean values of the reserves (18 billion $\left.\mathrm{m}^{3}\right)$. It is suggested to be considered as a territory of the second turn, which must be developed by using an experience obtained on the territories of the first turn [10].

The present geologic survey works (GSW) with the purpose of developing methane extraction technologies from coal beds are carried out on 16 plots in coal-bearing Donbas under special permission. But the lack of occluded and tied gas extraction technologies does not allow to expect positive results of geologic survey works (GSW) due to the obvious absence of technical-andtechnological equipment required for these kinds of works.

Research-and-commercial extraction of methane-gas is carried out in Lysychansk-Toshkivka area, where methane output amounted to 0.84 million $\mathrm{m}^{3}$ in 2017 . Methane loss due to coal mining amounted to 126.52 million $\mathrm{m}^{3}$ in 2017 .

\subsection{Shale gas}

Considerable perspectives for further increasing resource base of hydrocarbon gases in the Region and in the state in general are associated with shale gas resources development [9].

By the assessment of [9] who researched relationships of spatial and age-related rock expansion for perspective shale gas in Eastern oil-gas-bearing district of Ukraine within north-east part of the Dnipropetrovsk and partially of the Kherson regions there was singled out ZakhidnomykhailivskoPivdennoblyznyukivska perspective zone. It is attached to the southern Dnipro-Donetsk depression/fault rim. The zone extent makes up $128 \times 24$ kilometer approximately. Occurrence depth of sediments covering of Lower Carbon here varies from 1500 to $4000 \mathrm{~m}$.

Within the Dnipropetrovsk Region there are located Bagatoiska, Pereschepyne, Lychkove, Kremenivka, Kotivka, Kateryniva, Kernosivka, MykhailivskoPivnichnominivska, Leventsivka areas, in which mainly of them traditional oil-gas fields are exploited. Sediments of Lower Carbon, Upper-Vize and LowerSerpukhov sub-layers are perspective ones for shale gas exploration on this territory [11]. In the cut of UpperVize sediments the perspective clay thickness are made up mainly of dark-grey and up to black argillites. LowerSerpukhov sub-layers rocks are presented mainly by dark-grey argillites with minor interfacial layers of aleurolite, sometimes siderites or hard coal. By prior assessments [9] the production resources of shale gas of low-hard coal clay sediments within the whole perspective zone of 3027 square kilometers amount to 1756.7 billion $\mathrm{m}^{3}$ including free gas -801.3 billion $\mathrm{m}^{3}$ and occluded gas- 149.9 billion $\mathrm{m}^{3}$. Resources density on this territory amounts to 580.3 million $\mathrm{m}^{3}$, sediments occurrence depth is in the interval of $2500-4300 \mathrm{~m}$. By its geologic-production criteria ZakhidnomykhailivskoPivdennoblyznyukivska zone is the top-priority object for geologic-surveying works in shale gas exploration [9].

\section{Perspectives of energy industry development in the Dnipropetrovsk Region}

Thus, the ensuring its own fuel-energetic resources and their consumption within the Region are obviously unbalanced: steady power supply and efficient utility of energy resources in the Dnipropetrovsk Region are of top-priority problems which demand solution in order to exclude the drop in economic and social development of the society.

It is worth mentioning the following factors that influence energy efficiency of the Region's economy:

1. domination of power-consuming industries in economic structure;

2. tear and wear of fixed assets and out-of-date technologies;

3. the absence of the unified monitoring system and control over energy consumption;

4. the lack of introducing innovative technologies mechanisms;

5. the absence of anti-monopoly mechanisms at national and regional levels.

Energy efficiency of economy is directly connected with the use of fuel-energy resources (FER) nature, which must ensure steady economic development. National researchers understand the steady economic development as satisfying the needs of social-economic systems without limiting possibilities of the coming generations with regard to satisfying their needs [3, 12]. So, FER utility and energy efficiency should be considered in view of the concept of ecological efficient production, ecologically justified consumption and efficient management [3].

Experts mark out several criteria of FER rational usage [3]:

1. minimizing resources loss in the processes of production, supply, distribution, transformation and consumption;

2. attraction and utilization of secondary energy resources and waste products for their production;

3. development of market mechanisms in the sphere of ensuring and using energy resources;

4. increasing efficiency of FER consumption at the cost of introducing efficient technologies and increasing FER consumption efficiency;

5. maintenance of FER incremental value per capita in order to provide saving of natural capital value;

6. widening the sphere of utilization renewable energy sources in FER production and consumption;

7. limitation the government's interference which threatens unbalancing market regulation mechanisms of FER consumption and socio-economic development.

Providing energy safety of the Dnipropetrovsk Region as an industrially developed district at the expense of increasing energy efficiency in economy and developing alternative power industry is one of the top targets of the Dnipropetrovsk Region Strategy Development for the Period up to 2035, which is the basic document of the region's power engineering development. The Strategy envisages taking into account 
the economic, social and environmental priorities of energy-saving, energy efficiency and the region's power engineering development.

As mentioned above, high fuel consumption and a large portion of mineral fuel in the region's energy balance together with out-of-date technologies and inefficient exhaust gas-cleaning systems lead to high level of atmospheric pollution. That is why the major strategic targets [6] of the Region's power engineering development are determined as follows:

1. energy safety (planning of measures related to energy-saving and increasing energy efficiency level, decreasing GRP energy consumption capacity and energy renewal sources development);

2. "green" economy (promotion economic growth and decreasing power unbalance owing to renewal energy development);

3. clean environment (improvement of the human environment and quality of life).

So, in 2018 on the territory of the Dnipropetrovsk Region 13 solar power stations (SPS) were put into operation amounting to 38 units in total. In 2018 SPS of the region produced 37 million $\mathrm{kW} /$ year of electric power, which corresponds to annual consumption by Novomoskovsk District. The most powerful solar station operates in Nikopol (32 screens of $10 \mathrm{MW}$ output) built by investors from Canada (project cost EUR 11 million). Chinese investors are building SPS for EUR 230 million near Starozavodske village of Nikopol District.

On the Region's territory six biogas installations have been put into operation and the development of wind-power engineering is being planned.

\section{Conclusions}

The analysis of consumption and energy resources ensuring of the Dnipropetrovsk Region performed by us allows to state as follows:

1. In the structure of the Region's consumption energy resources hard coal prevails $(39.2 \%)$, coke and semicoke of hard coal; gas coke $(28.6 \%)$ and natural gas $(13.8 \%)$.

2. The main consumers of energy resources in the Region are steel producers, the share of which amounts to $63.1 \%$ of total volumes of consumption, electric power stations, population and industrial enterprises.

3. In the Region there is actual unbalance between the levels of ensuring own natural gas resources and its consumption which demands investment into exploration and mining works at the deposits of traditional and alternative energy carriers.

4. At present, brown coal mining at the known deposits in the Region is not reasonable due to the limit of their reserves and of problematic methods of their extraction.

5. In the Region there are potential possibilities for increasing output of both hard coal and coking coal, but its mining should be limited to the available volumes. Technological re-equipment became actual in coal mining industry, which will allow optimizing coal extraction in the Region in view of ecology problems.
6. Methane as an accompanying useful mineral is present in coal beds of Carbon age in the north of the Region within Pavlogradsk-Petropavlivsk geologicindustrial district.

The district with average values of the reserves (18 billion $\mathrm{m}^{3}$ ) is proposed to be considered as a territory of the second turn, which must be developed by using an experience obtained in gas extraction on the territories of the first turn with considerable reserves.

7. For the perspective exploration of shale gas in the Region are sediments of Lower Carbon, in particular Upper-Vize and Lower-Serpukhov sub-layers on the territories where traditional oil-gas deposits are exploited. Top-priority object to carry out geologic explorative works for shale gas is Zakhidnomykhailivsko-Pivdennoblyznyukivska zone. The production resources of shale gas of low-hard coal clay sediments within the whole perspective zone amount to 1756.7 billion $\mathrm{m}^{3}$ including free gas 801.3 billion $\mathrm{m}^{3}$ and occluded gas -149.9 billion $\mathrm{m}^{3}$.

8. The solution of the problem of energy intensive industries in the Dnipropetrovsk Region has a complex character and requires finding efficient solutions concerning regulation of energy resources consumption by using stimulating, compulsory and educative measures. Top-priority directions of the state and regional policy in the sphere of energy-saving must be decreasing energy intensity and introducing alternative types of energy.

\section{References}

1. L. Melnyk, O. Pashechko, VZHNAU 1 (2), 348-355 (2012)

2. Palyvno-enerhetychni resursy Ukrainy: Statystychnyi Zbirnyk (Fuel and energy resources of Ukraine, Statistical Publication, Kyiv, 2019), http://ukrstat.gov.ua/druk/publicat/kat_u/2019/zb/12 /zb_per2018.pdf. Accessed 21 Jan 2020

3. M. Mazur, VCHNU: Ekon. 6 (1), 110-114 (2014)

4. Vykorystannia enerhetychnykh materialiv i produktiv pereroblennia nafty (Express release: Use of energy materials and oil products 2011 - 2019), http://www.dneprstat.gov.ua/expres/index.htm. Accessed 29 Jan 2020

5. Valovyi rehionalnyi produkt (St. zb. K. 2019), (Statistical Yearbook: Gross Regional Product 2019),

http://ukrstat.gov.ua/druk/publicat/kat u/2019/zb/04 /zb_vrp_2017.pdf. Accessed 29 Dec 2019

6. Stratehiia enerhozberezhennia, enerhoefektyvnosti ta rozvytku vidnovliuvalnykh dzherel enerhii Dnipropetrovskoi oblasti na 2018-2035 (Energy Saving Strategy for Energy Efficiency and Renewable Energy Sources of Dnipropetrovsk Region for the Period up 2018 to 2035) (2017), https://oblrada.dp.gov.ua/rishennia/sklikannia-7/xisesiya/\%E2\%84\%96-275-11vi\%D1\%96-01-122017/ Accessed 18 Jan 2020 
7. Annual Mineral resources of Ukraine (DNVP Heoinform Ukrainy, Kyiv, 2014 - 2018), http://geoinf.kiev.ua/publikatsiyi/shchorichnyky/min eralni-resursy-ukrayiny/. Accessed 1 Nov 2019

8. Vydobutok vuhillia $\mathrm{v}$ Ukraini $\mathrm{v}$ rozrizi shakht (Coal output at mines in 2018), http://mpe.kmu.gov.ua/minugol/control/uk/publish/a rticle?art_id $=245272736 \&$ cat_id $=245183238$. Accessed 1 Feb 2020

9. S. Vakarchuk, O. Zeikan, T. Dovzhok et al., Netradytsiini dzherela vuhlevodniv Ukrainy, (Nontraditional sources of hydrocarbons of Ukraine), ed. by O. Zeikan, vol. 5. (VTSPRYNT, Kyiv 2013), p. 240

10. N. Khomenko, Osoblyvosti formuvannya skupchen' metanu u rayonakh nyz'koho ta seredn'oho stupenya metamorfizmu (Peculiarities of formation of methane conclusions in low and medium degrees of metamorphism), in International Scientific and Technical Conference "Oil and gas industry: Prospects for building up resource base" IGG 2018, ed. by V. Khomin, S. Kurovets, V. Omelchenko, Ivano-Frankivsk, Ukraine, May 2325, 2018, pp. 57-61

11. V. Mykhailov, Netradytsiini dzherela vuhlevodniv Ukrainy (Non-traditional sources of hydrocarbons of Ukraine). (Naftohaz Ukrainy, Nika-Tsentr, Kyiv, 2013), p. 368

12. H. Deili, Poza zrostanniam. Ekonomichna teoriia staloho rozvytku (Out of growth. Economic theory of sustainable development). (Intelsfera, Kyiv, 2002), p. 48

13. A. Deina, EOU 1 (25), 160-169 (2017)

14. S. Denysiuk, EETE 4, 7-28 (2017)

15. D. Hertsmark, H. Tonkhauzer, K. Muts, M. Sura, O. Kyshko-Yerli, Slantsevyi haz Ukrainy: ekolohichna i normatyvno-pravova otsinka (Shale gas in Ukraine environmental and regulatory assessment), vol. $\quad 1 \quad$ (2012), https://web.archive.org/web/20130215041558/menr. gov.ua/content/article/11434. Accessed 25 Mar 2020

16. Interaktyvna karta Mineralni resursy Ukrainy (Interactive map Mineral resources of Ukraine) (2019), http://mineralsua.info/mapviewer/goruchi.php. Accessed $25 \mathrm{Dec}$ 2019

17. V. Lir, EIP 2, 110-131 (2016)

18. L. Iakushenko, Ye. Yakovliev, Perspektyvy vydobutku slantsevoho hazu v Ukraini: ekolohichni aspekty (The prospect of shale gas production in Ukraine: environmental aspects) (2012) http:niss.gov.ua/content/articles/files/slanets. Accessed 12 Dec 2019

19. Yu. Makohon, V. Koshelenko, Str. Pan. 1, 121-127 (2007)

20. M. Syvyi, V. Kitura, NZTNPU: Geog. 1, 225-232 (2013)

21. M. Syvyi, NZTNPU: Geog. 1, 136 (2010)
22. A. Yerina, O. Kolodiazhna, NZEN 19, 40-44 (2001)

23. M. Yevdoshchuk, M. Korzhniev, M. Kurylo, Ye. Yakovliev, Strat. Pan. 1(38), 27-35 (2010)

24. K. Zhadko, TPAEIP 16, 302-307 (2017)

25. O. Zurian, A. Liashok, MRU. 3, 30-39 (2019)

26. S. Zavgorodnya, Faktori viniknennya energetichnoyi bidnosti ta prioritetni napryami yiyi podolannya (Energy poverty factors and priority areas updates). (Institut strategichnih doslidzhen, 2017). http://www.niss.gov.ua/content/articles/files/energet _bidnist-66a29.pdf. Accessed 13 Dec 2019

27. Mineral resources of Ukraine (2020), http://minerals-ua.info. Accessed 31 Mar 2020

28. Heoinform Ukrainy (2019), http://geoinf.kiev.ua/. Accessed 31 Mar 2020

29. Dnipropetrovsk regional council (2020), https://oblrada.dp.gov.ua/. Accessed 31 Mar 2020

30. Statistical Department of Statistics in the Dnipropetrovsk region (2020), http://www.dneprstat.gov.ua/. Accessed 31 Mar 2020 